\title{
An inventory and topographic analysis of glaciers in the Torngat Mountains, northern Labrador, Canada
}

\author{
Robert G. WAY, ${ }^{1}$ Trevor BELL, ${ }^{1}$ Nicholas E. BARRAND ${ }^{2}$ \\ ${ }^{1}$ Department of Geography, Memorial University of Newfoundland, St John's, Newfoundland and Labrador, Canada \\ E-mail: rway024@ottawa.ca \\ ${ }^{2}$ School of Geography, Earth and Environmental Sciences, University of Birmingham, Birmingham, UK
}

\begin{abstract}
This study presents the first complete glacier inventory of the Torngat Mountains, northern Labrador, Canada. In total, 195 glaciers and ice masses are identified, covering a total area of $24.5 \pm 1.8 \mathrm{~km}^{2}$. Mapped ice masses range in size from 0.01 to $1.26 \mathrm{~km}^{2}$, with a median size of $0.08 \mathrm{~km}^{2}$. Ice masses have a median elevation of $776 \mathrm{~m}$ a.s.l. and span an altitudinal range of $290-1500 \mathrm{~m}$ a.s.l. Indications of ice flow suggest at least $\mathbf{1 0 5}$ active glaciers in the Torngat Mountains. Analysis of morphometric and topographic parameters suggests that the regional distribution of ice masses is linked to physiographic setting while the preservation of coastal ice masses at low elevation is related to local meteorological conditions. In the most coastal environments, ice masses are shown to exist below the regional glaciation level due to topographic shadowing, coastal proximity and widespread debris cover. This study provides a baseline for future change assessment.
\end{abstract}

KEYWORDS: Arctic glaciology, glacier mapping, mountain glaciers, remote sensing

\section{INTRODUCTION}

Melting over the past century on many glaciers and ice caps has been greater than during any other period of the preceding several millennia (Anderson and others, 2008; Sharp and others, 2011a; Fisher and others, 2012; Thompson and others, 2013). The near-worldwide retreat of glacier ice has resulted in accelerating contributions of glaciers to global sea-level rise (SLR) (e.g. Meier and others, 2007; Church and White, 2011; Gardner and others, 2013) and it is projected that glacier surface mass loss alone will contribute $0.16-0.22 \pm 0.04 \mathrm{~m}$ to SLR during the next century (Radić and others, 2014). Mountain glaciers, in particular, are extremely sensitive to changes in climate (e.g. Meier, 1984) and some have endured rapid disintegration over the past decade (e.g. Paul and others, 2004), leading to projections that half of all small mountain glaciers $\left(5 \mathrm{~km}^{2}\right)$ will disappear in the next century (e.g. Radić and Hock, 2011). With the advent of remote-sensing technologies, the ability to survey glacierized landscapes has vastly improved over the past 40 years (Pellilka and Rees, 2009). Satellite sensors such as the Advanced Spaceborne Thermal Emission and Reflection Radiometer (ASTER) and Landsat have enabled the construction of complete, precise glacier inventories in otherwise inaccessible locations (Kääb, 2005). Automated and semi-automated glacier classification techniques and the widespread availability of digital elevation models (DEMs) have increased overall mapping resolution and accuracy while decreasing classification time (e.g. Kääb and others, 2002; Paul and Kääb, 2005).

Initiated in 1998, the Global Land Ice Measurements from Space (GLIMS) project has as its primary goal to map and monitor all the world's glaciers using data from satellite sensors (Bishop and others, 2004; Racoviteanu and others, 2009). The GLIMS program has led to comprehensive glacier inventories in many polar and alpine regions and contributes to regional glacier change assessments (e.g. Knoll and others, 2009; Paul and Andreassen, 2009; Barrand and Sharp, 2010; Bolch and others, 2010; Paul and Svoboda, 2010; Davies and Glasser, 2012; Pan and others, 2012). As a result, glacier inventories utilizing GLIMS protocols have contributed to a near-globally complete dataset of glacier outlines (Arendt and others, 2013). The Torngat Mountains of northern Labrador (Fig. 1 inset), are one of the few remaining glacierized regions in the Arctic yet to be comprehensively inventoried as part of the GLIMS initiative and there is currently little baseline information available on the state of glaciers and ice masses in the region. These features occupy the southern limit of glacierization in the eastern Canadian Arctic, making them of particular interest for scientific study.

This paper presents the first complete inventory and classification of the ice masses of the Torngat Mountains. Adopting standard protocols established by GLIMS, the study compiles baseline data on Torngat ice masses and examines local and regional setting in detail. Trends in ice mass morphometry, geographic location and topographic setting are presented and compared with those from other northern alpine environments. The challenges encountered in mapping and classifying Torngat ice masses according to the GLIMS framework are also discussed. For the purposes of this study, we use the term ice mass to include all mapped glaciers and ice masses in the Torngat Mountains while the term glacier is used exclusively for the subset of ice masses that display signs of active flow.

\section{STUDY AREA}

The Torngat Mountains are the southernmost mountain range in the eastern Canadian Arctic and are the only zone of Arctic Cordillera south of Baffin Island (Fig. 1). They are characterized by prominent relief in excess of $1000 \mathrm{~m}$, with the highest peaks occurring $\sim 20 \mathrm{~km}$ inland south of Nachvak Fiord (Mount Caubvick, 1652 ma.s.l.). Geologically, the Torngat Mountains are defined by the Torngat Orogen, with the regional geology being primarily of Precambrian to Archean age (Wardle and others, 1992). The region consists of both the Churchill and Nain structural 


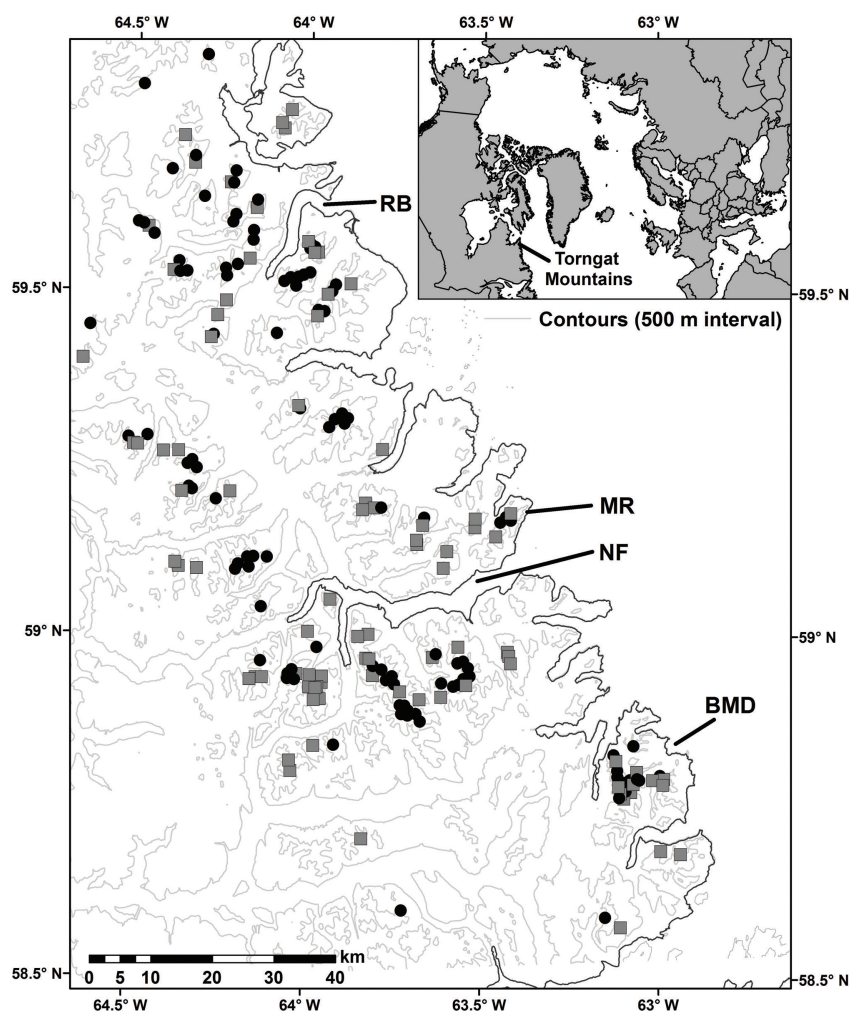

Fig. 1. Map of the Torngat Mountains and adjacent coastline. Symbols depict ice masses mapped in 2005 for this study (black circles: active ice masses; grey squares: inactive ice masses). Locations discussed in the text are abbreviated on the map as follows: Blow Me Down Mountains (BMD), Nachvak Fiord (NF), Mount Razorback (MR) and Ryan's Bay (RB). The location of the Torngat Mountains is shown relative to circum-arctic and middle northern latitudes (inset).

provinces (Wardle and others, 1997). The bedrock geology is mostly orthogneiss and granite near the coast and undifferentiated gneiss farther inland $(\sim 40 \mathrm{~km}$ from the coast), though there are sections of sedimentary rocks in the south and several intrusions of igneous rocks in the north (Clark, 1991; Wardle and others, 1997).

The Torngat Mountains form part of the Canadian Shield and contain two main physiographic regions: the George Plateau stretching from Ungava Bay to the Quebec-Labrador drainage divide; and the fretted mountains within $40 \mathrm{~km}$ of the Labrador Sea coastline (Bostock, 1970). The George Plateau slopes upwards at $\sim 10 \mathrm{~m} \mathrm{~km}^{-1}$ from near sea level in Ungava Bay to a maximum height of $\sim 1000 \mathrm{~m}$ a.s.l. in the Torngat Mountains (Fig. 2a). Maximum elevations occur in the central Torngat Mountains, with decreasing elevation northwards (Fig. 2b). The fretted coastal mountains contain the greatest relief $(>1000 \mathrm{~m}$ ) with widespread cirque development. By contrast, inland cirques are less numerous and mostly form along the margins of the upland plateau. Selective linear erosion during previous glaciations of the region has resulted in the dramatic fiord and deep valley systems that predominantly run west-east through the Torngat Mountains (e.g. Marquette and others, 2004; Staiger and others, 2005).

\section{Climate}

The Torngat Mountains are classified as polar tundra (ET) under the Köppen-Geiger climate classification (Kottek and others, 2006), with the most similar bioclimatic regions
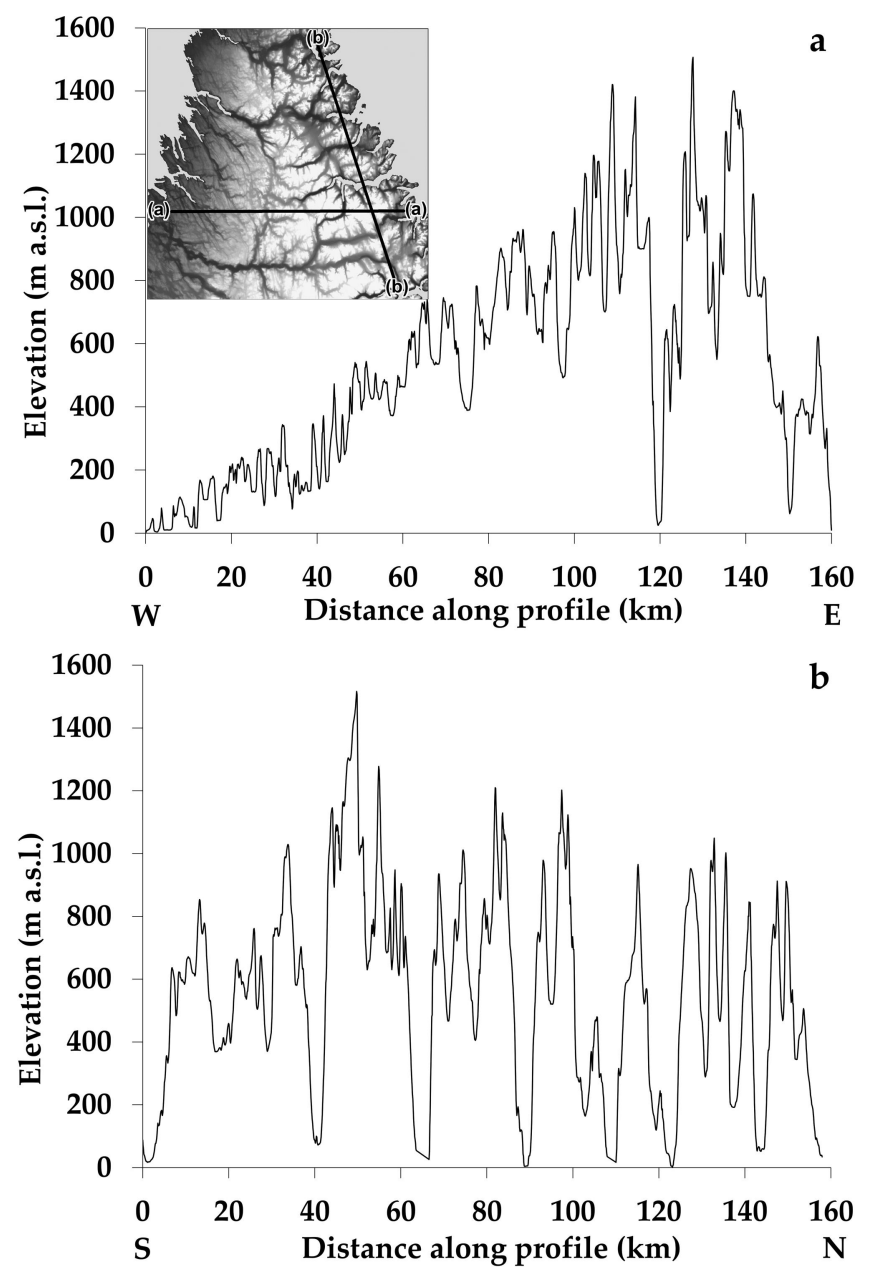

Fig. 2. Topographic profiles across the Torngat Mountains extracted from a Canadian National Topographic Database DEM. (a) Westeast longitudinal transect from Ungava Bay in the west to the Labrador Sea coastline along latitude $58.8^{\circ} \mathrm{N}$. (b) South-north latitudinal transect from Saglek Fiord to Eclipse River inland of the Labrador Sea coastline.

located in eastern Baffin Island, West Greenland, northern Sweden and Svalbard (Metzger and others, 2013). Synoptically, the Labrador Current has a pervasive influence on regional climate in the Torngat Mountains by transporting cold Arctic water southwards along the coast (Banfield and Jacobs, 1998). During the summer this leads to maritime conditions with lower temperatures and pervasive fog; in the winter, however, the formation of seasonal sea ice on the Labrador Sea leads to very cold and dry continental conditions (Maxwell, 1981). Regional wintertime precipitation (i.e. snowfall) is generated by medium- to lowintensity winter storms that are steered by the Canadian Polar Trough, which influences the positions of the Polar and Arctic fronts in northeastern Canada. Prevailing winds in the Torngat Mountains are generally greatest in the winter and lowest in the summer, with the predominant wind direction being westerly, though complex topography creates much local variability (Canadian Wind Energy Atlas; www.windatlas.ca) (e.g. Frey-Buness and others, 1995; Benoit and others, 2002).

Summary climate data for the Torngat Mountains (58.2$\left.60.4^{\circ} \mathrm{N}, 62.2-64.3^{\circ} \mathrm{W}\right)$ are estimated using ERA-Interim reanalysis (Dee and others, 2011) due to the lack of reliable weather stations in the region (e.g. Way and Viau, in press) 
and because it has been shown to accurately model changes in Arctic precipitation and temperature (Lindsay and others, 2014; Cowtan and Way, 2014). Over the period 19792009 , mean annual air temperatures were -6.2 and $-8.5^{\circ} \mathrm{C}$ at the surface ( 2 ma.s.l.) and $850 \mathrm{mbar}$ ( $1500 \mathrm{ma.s.l}$.), respectively (Fig. 3). The 850 mbar height approximates the elevation of the highest ice masses in the Torngat Mountains. Mean summer temperatures (June-August) varied between $4.9^{\circ} \mathrm{C}$ at the surface and $2.7^{\circ} \mathrm{C}$ at $850 \mathrm{mbar}$. Total precipitation in the region averaged $0.73 \mathrm{ma}^{-1}$ between 1979 and 2009, with most precipitation occurring in the fall $(\sim 230 \mathrm{~mm})$ and summer $(\sim 210 \mathrm{~mm})$.

\section{Torngat ice masses}

The earliest observations on ice masses in the Torngat Mountains date to the early 20th century (e.g. Odell, 1933), while systematic mapping by Forbes and others (1938) and Henoch and Stanley (1968) generated two preliminary inventories that identified $\sim 60$ ice masses north of Nachvak Fiord. Mass-balance data were collected between 1981 and 1984 on four glaciers in the Selamiut Range, south of Nachvak Fiord, by Rogerson (1986). Results indicated overall negative mass balance for three of the four glaciers (Rogerson, 1986), and the importance of snowfall accumulation in local glacier mass balance and glacier debris cover for surface melt rates (Rogerson and others, 1986a). The mass-balance records support areal changes on ten glaciers between 1964 and 1979 measured by Stix (1980), of which the majority (eight) were either stagnant or retreating. McCoy (1983) and Rogerson and others (1986b) both explored historical glacier variability and glacial geomorphology in several glacierized valleys south of Nachvak Fiord. McCoy (1983) dated maximum Neoglacial activity to within the past 4000 years, with abandonment of Little Ice Age (LIA) moraines in the early 15th century. In contrast, Rogerson and others (1986b) attributed a much more recent age ( 1000 years ago) to Neoglacial advances and placed the retreat from LIA positions to within the past 100 years.

More recently, in a pilot study of change detection on a subset of the 96 largest Torngat glaciers, Brown and others (2012) documented a 9\% decrease in ice area between 2005 and 2008 using glacier outlines mapped from SPOT5 (Satellite Pour l'Observation de la Terre) imagery (2008) and this study (2005). The recent reduction of glacier ice in the Torngat Mountains was interpreted as a response to both higher summer air temperatures and a multi-decadal decline in winter precipitation (Brown and others, 2012). A full analysis of change detection over the past 60 years for all glaciers and ice masses in the Torngat Mountains, including field surveys, is currently in progress.

\section{METHODS}

\section{Data collection}

Ice masses were mapped using late-summer (August 2005) 1:40000 colour aerial photography provided by Parks Canada. Photographs were scanned at $1 \mathrm{~m}$ ground resolution and orthorectified in the remote-sensing software PCl Geomatica to correct for terrain distortion due to high relief (e.g. Kääb, 2005). Orthorectification was conducted using image orientation parameters provided by the surveyor $(\mathrm{X}, \mathrm{Y}, \mathrm{Z}$, Omega, Phi, Kappa) and manually collected tie points. This method was used instead of ground control points (GCPs) because of the lack of reliable GCPs across most of the region

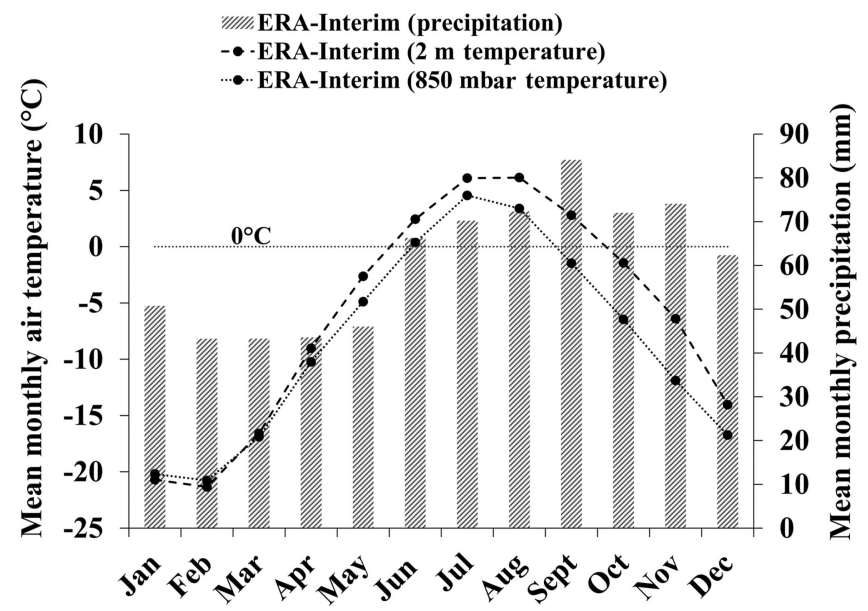

Fig. 3. Average monthly precipitation and monthly temperature for the Torngat Mountains derived from ERA-Interim reanalysis for the period 1979-2009 (Dee and others, 2011). Monthly temperatures provided for both 2 and $\sim 1500$ m a.s.l. (850 mbar) altitude. Dotted horizontal line depicts $0^{\circ} \mathrm{C}$.

and because the former produced a lower root-mean-square error (RMSE) $(\sim 2.5 \mathrm{~m})$ than the latter $(\sim 4.0 \mathrm{~m})$. An $18 \mathrm{~m}$ resolution DEM derived from Canada's National Topographic Database (NTB) ( $\pm 15 \mathrm{~m}$ vertical accuracy) was used for orthorectification. In total, $\sim 500$ digital orthophotos were produced, allowing for each ice mass to be imaged in at least two orthophotos. Terrain parameters for each ice mass were measured from the NTB DEM provided by Parks Canada. SPOT5 high-resolution geometric (HRG) (5 m resolution, late summer 2008) and Landsat 7 Enhanced Thematic Mapper Plus (ETM+) (15 m resolution, late summer 1999) satellite data were used to search for ice masses not included in the initial air photo inventory.

Our preliminary ice mass database contained all possible ice masses, including active and inactive ice masses, and perennial ice patches. Differentiation between late-summer snowfields and ice masses was only possible where bare ice was visible on imagery. Given the resolution of the aerial photography $(1 \mathrm{~m})$, the minimum size limit for ice masses was set to $0.01 \mathrm{~km}^{2}$, similar to other recent studies (e.g. Paul and Andreassen, 2009; Paul and others, 2009; Svoboda and Paul, 2009; Stokes and others, 2013). For ice mapping, this study used the GLIMS definition of a glacier and follows established GLIMS protocols (Rau and others, 2005; Raup and Khalsa, 2010). Lateral meltwater streams and lakes were used to trace indistinct ice margins. Mapping of ice masses with heavy debris cover followed the assumed geometric shape of the ice mass, in addition to consideration of debris banding, flowlines and changes in surface slope (e.g. Rau and others, 2005; Racoviteanu and others, 2009). Ice masses were also obliquely viewed in three dimensions by draping satellite images and aerial photographs over the DEM in ESRI's ArcScene to aid in the visual interpretation and classification of ice boundaries.

\section{Mapping error assessment}

Total error for mapped ice margins is difficult to quantify due to the lack of in situ margin measurements covering the same period as the aerial photography and because of inherent discrepancies in the mapping technique used by different operators (e.g. Paul and others, 2013). Following 


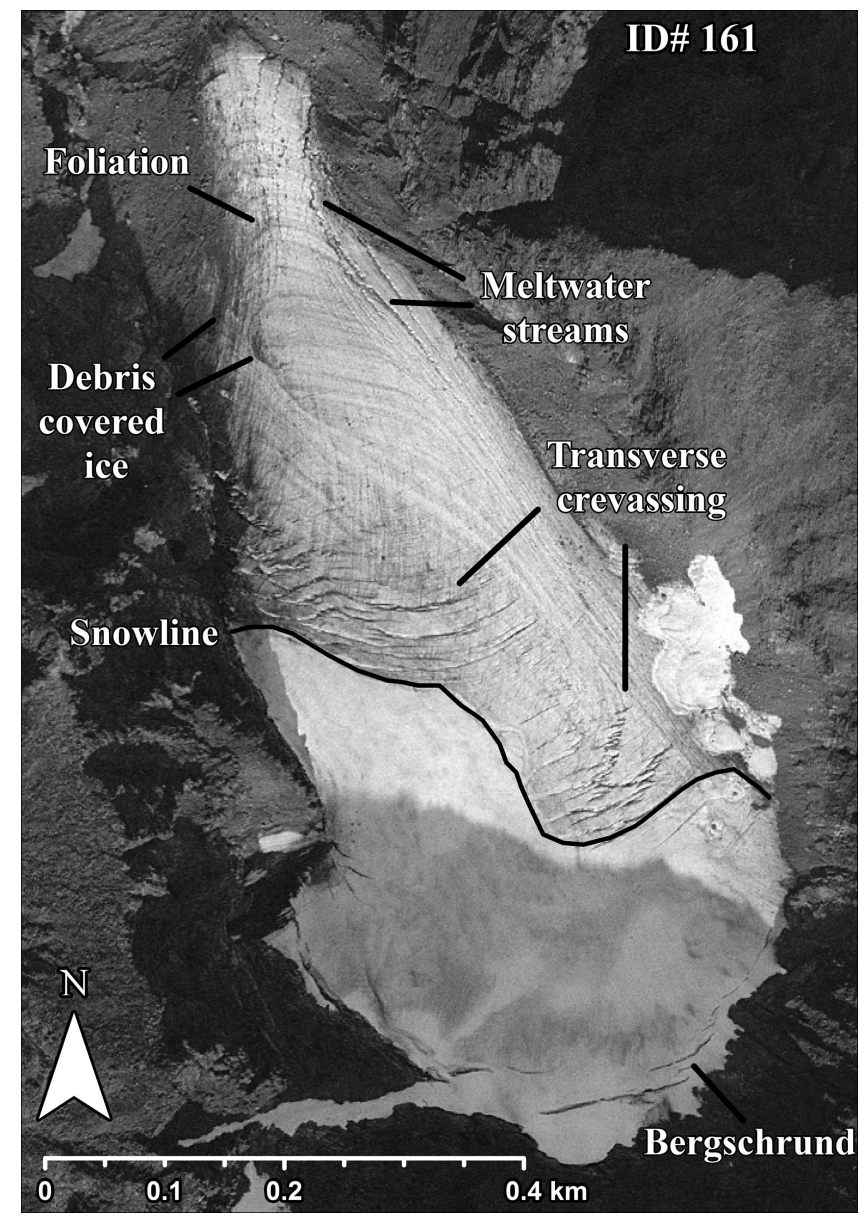

Fig. 4. Aerial photograph of an actively flowing mountain glacier near Ryan's Bay $\left(52.53^{\circ} \mathrm{N} 64.00^{\circ} \mathrm{W}\right)$ in the Torngat Mountains. The image is labeled with examples of glaciological features that categorize glacier flow.

the recommendations of Paul and others (2013), two operators independently re-mapped the margins of 11 ice masses $(10 \%$ of total ice area) that were selected to reflect the characteristics of the overall population (e.g. debriscovered/debris-free, large/small, shadowed/unshadowed). The RMS difference between the inventory subsets $\left(0.007 \mathrm{~km}^{2}\right)$ corresponds to a mapping error of $\sim 2 \mathrm{~m}$ along ice mass margins. We use a buffer of $\pm 5 \mathrm{~m}$ on either side of our mapped ice margins to integrate cumulative errors from mapping $(\sim 2.0 \mathrm{~m})$, orthorectification $(\sim 2.5 \mathrm{~m})$ and planimetry, as suggested by Granshaw and Fountain (2006) and Bolch and others (2010).

\section{GLIMS classification}

Ice mass classification was aided through the use of colour aerial photography, satellite imagery, limited field observations and consultation with historical aerial photography. Classification followed the protocols established by GLIMS and used the GLIMS Analysis Tutorial (Raup and Khalsa, 2010), GLIMS Glacier Classification Manual (Rau and others, 2005) and several comprehensive publications (Raup and others, 2007; Racoviteanu and others, 2009). The adapted classification scheme proposed by the GLIMS Antarctic Regional Center was used because it incorporates a parameter that quantifies the debris cover on a glacier (Rau and others, 2005, 2006). Under this classification scheme, ice masses were first classified from ten primary glacier types, and then from nine different forms. Although not discussed in this paper, several other parameters were reported following GLIMS protocols including ice mass frontal characteristics, longitudinal profile, presumed major source of nourishment, recent activity of glacier tongue, presence of moraines and debris coverage of glacier tongue.

\section{Active glacier ice}

Ice masses with evidence of glacier flow were subdivided in the database, and their characteristics compared with those of inactive ice masses. Glacier flow was recognized through the identification of crevasses, debris banding and foliations (Fig. 4). Looped debris banding and transverse crevasses, for example, common on Torngat glaciers, are indicative of differential glacier movement (Benn and Evans, 2010). The absence of evidence of active flow for an individual ice mass does not preclude the possibility of actively flowing ice; however, without visible evidence of flow, an ice mass could not be classified as an active glacier.

\section{Ice mass distribution, morphometry and topographic setting}

A variety of morphometric and topographic parameters were collected to summarize the local setting of Torngat ice masses in relation to their altitudinal and spatial distributions. This computation mostly followed methods provided in DeBeer and Sharp (2009) and Paul and others (2010). Aspect was measured following the median flowline in cardinal directions $(\mathrm{N}, \mathrm{NE}, \mathrm{NW}, \mathrm{S}, \mathrm{SE}, \mathrm{SW}, \mathrm{W}, \mathrm{E})$. Length $(\mathrm{km})$ was measured along ice mass centre lines parallel to flow direction while distance to coast was measured as the Euclidean distance $(\mathrm{km})$ between ice mass centroids and the nearest Labrador Sea coastline. Area-weighted elevation (ma.s.l.; minimum, mean, maximum) and mean slope $\left({ }^{\circ}\right)$ were determined by collecting the zonal statistics from DEM and slope rasters of ice mass polygons. This method was also used to calculate mean area-weighted incoming solar radiation $\left(\mathrm{Wh} \mathrm{m}^{-2}\right)$ using clear-sky insolation (direct and diffuse) calculated for the melt season midpoint (1 August) in ArcGIS 10 (Fu and Rich, 2002).

Debris cover (\%) included only the debris cover that obscured underlying ice surfaces for each ice mass. Compactness, a measure of ice mass shape and morphometry, was collected using the formula $\left(4 \pi\right.$ Area)/(Perimeter ${ }^{2}$ ) after DeBeer and Sharp (2009). Mean back-wall height was calculated from the elevation difference between a glacier basin's ridge crest and the upper ice margin parallel to the back-wall ridge. Relative upslope area was computed as a ratio between ice mass area and total upslope area, with the latter calculated as the area between each basin's ridge crest and upper ice margin. Upslope area was also used to derive the mean contributing area slope $\left(^{\circ}\right)$ by averaging a slope raster for mapped upslope areas.

Relationships between geographic/topographic factors and ice mass characteristics were investigated through correlation analysis and visual inspection of scatter plots. Tests for the degree of association between indices used the non-parametric Spearman rho rank correlation coefficient $\left(r_{\mathrm{s}}\right)$ (e.g. DeBeer and Sharp, 2009) for interval, ordinal and highly skewed indices, and the Pearson correlation coefficient $(R)$ for continuous data that show linear relations (Mann, 2007). Additionally, ice masses were compared based on their flow activity (active vs inactive) and physiographic region (fretted vs plateau). Indices were first 
tested for normality using the Shapiro-Wilk test (Royston, 1995), and then the statistical significance of differences between populations was assessed using both the Student's t-test (Mann, 2006) and the non-parametric KolmogorovSmirnov test (Conover, 1999; Marsaglia and others, 2003).

\section{RESULTS}

\section{Size distribution of ice masses}

In 2005, 195 ice masses existed in the Torngat Mountains, covering a total area of $24.51 \pm 1.80 \mathrm{~km}^{2}$ (Table 1). The size distribution is highly skewed to smaller ice masses, with almost a third smaller than $0.05 \mathrm{~km}^{2}$ and only eight larger than $0.5 \mathrm{~km}^{2}$ (Fig. 5). The 30 largest ice masses made up almost $50 \%$ of the total ice area, whereas the 30 smallest ice masses covered only $2.8 \%$ of the total area. The median ice mass area was $0.07 \mathrm{~km}^{2}$ (range $0.01-1.26 \mathrm{~km}^{2}$ ), and the median ice mass length was $0.33 \mathrm{~km}$ (range $0.04-2 \mathrm{~km}$ ). In total, 49 ice masses were longer than $0.5 \mathrm{~km}, 8$ longer than $1.0 \mathrm{~km}$ and 15 shorter than $0.1 \mathrm{~km}$. Ice masses in the Torngat Mountains span slightly more than $1^{\circ}$ of latitude (58.6$59.9^{\circ} \mathrm{N} ; \sim 170 \mathrm{~km}$ ) and occur within $50 \mathrm{~km}$ of the Labrador Sea (Table 1; Fig. 1). Ice masses more commonly occur in the fretted mountain region $(68 \% ; 80 \%$ of ice area) adjacent to the Labrador Sea (Table 1). For the most part, ice mass forms are evenly distributed across the region, except for summit ice masses that predominantly occur inland and farther north.

\section{Classification of ice masses}

Three primary ice mass types were classified in the Torngat Mountains: valley glacier $(n=1)$, mountain glacier $(n=96)$ and glacieret/snowfield ( $n=94$; Table 1 ). The most common ice mass forms were cirque $(n=86)$ and remnant ice $(n=41)$, the remainder being simple and compound basin

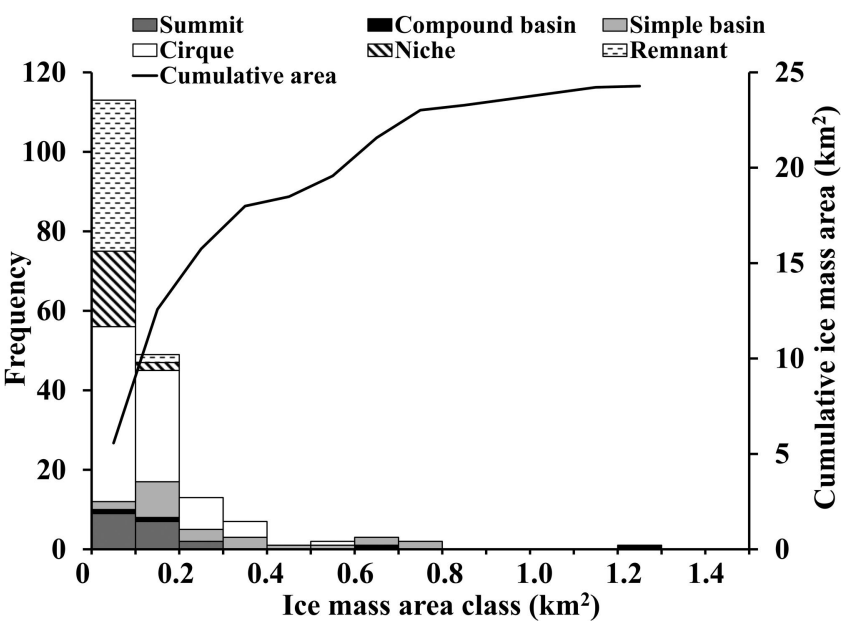

Fig. 5. Size-frequency distribution of ice masses in the Torngat Mountains. Bars are subdivided using ice mass forms classified from GLIMS protocols. Line depicts the cumulative area distribution for Torngat ice masses.

glaciers $(n=26)$, niche ice masses $(n=23)$ and summit ice masses $(n=19)$. Eighty percent of the total ice area in the Torngat Mountains occurs as either cirque (42\%) or simple and compound basin (38\%) forms. Most Torngat ice masses $(83 \%)$ have some debris cover (median percentage debris cover $13 \%$ ), and roughly one-quarter are $>25 \%$ debriscovered (Table 1$)$.

\section{Ice mass characteristics}

Torngat ice masses span an elevational range between 294 (lowest ice mass snout) and 1479 ma.s.l. (highest upper ice margin) and have a median area-weighted mean elevation of $775 \mathrm{~m}$ a.s.l. Distance from the Labrador Sea explained about half of the variance $\left(r^{2}=0.51\right)$ observed in the

Table 1. Median values for geographic, topographic and morphometric variables subdivided by ice mass form, flow status and physiographic setting. Table includes ice mass counts (Count; $n)$, cumulative area $\left(\right.$ CumulArea; $\left.\mathrm{km}^{2}\right)$, individual ice mass area $\left(\right.$ Area; $\left.\mathrm{km}^{2}\right)$, ice mass length (Length; $\mathrm{km}$ ), ice mass latitude (Latitude; ${ }^{\circ} \mathrm{N}$ ), distance to coastline (D2Coast; $\mathrm{km}$ ), ice mass mean elevation (Elevation; ma.s.I.), ice mass slope (Slope; ${ }^{\circ}$ ), compactness (Compact; undefined), incoming solar radiation (Solar; $\mathrm{Wh} \mathrm{m}^{-2}$ ), mean back-wall height $(\mathrm{BWH} ; \mathrm{m})$, relative upslope area (RelUA; ratio), contributing area slope (CASlope; ${ }^{\circ}$ ), percentage debris cover (DBCover; \%), count of active ice masses (Nactive; $n$ ), percentage of active ice masses (\%active; \%) and predominant direction (Aspect; north or north-northeast)

\begin{tabular}{|c|c|c|c|c|c|c|c|c|c|c|}
\hline Type/variable & Total & Summit & Compound basin & Simple basin & Cirque & Niche & Remnant & Active & Fretted & Plateau \\
\hline Count & 195 & 19 & 3 & 23 & 86 & 23 & 41 & 105 & 132 & 63 \\
\hline CumulArea & 24.51 & 2.13 & 2.07 & 7.03 & 10.35 & 1.19 & 1.66 & 19.83 & 19.27 & 5.25 \\
\hline Area & 0.07 & 0.09 & 0.7 & 0.21 & 0.09 & 0.05 & 0.03 & 0.14 & 0.08 & 0.06 \\
\hline Length & 0.33 & 0.37 & 1.06 & 0.74 & 0.34 & 0.18 & 0.15 & 0.42 & 0.33 & 0.3 \\
\hline Latitude & 59.11 & 59.27 & 59.1 & 58.96 & 59.09 & 59.16 & 59.1 & 59.19 & 59.14 & 59.1 \\
\hline Elevation & 775 & 933 & 846 & 780 & 808 & 720 & 695 & 788 & 698 & 933 \\
\hline Slope & 28 & 23 & 23 & 23 & 28 & 33 & 34 & 25 & 27 & 30 \\
\hline Compact & 0.39 & 0.39 & 0.25 & 0.44 & 0.44 & 0.33 & 0.25 & 0.45 & 0.4 & 0.36 \\
\hline Solar & 3068 & 3599 & 2903 & 3092 & 3076 & 3102 & 2680 & 3112 & 3034 & 3183 \\
\hline BWH & 227 & 0 & 432 & 250 & 234 & 209 & 251 & 227 & 250 & 170 \\
\hline UpArea & 0.13 & 0 & 0.99 & 0.3 & 0.17 & 0.09 & 0.11 & 0.18 & 0.17 & 0.1 \\
\hline RelUA & 1.82 & 0 & 1.31 & 1.09 & 1.82 & 1.86 & 3.32 & 1.35 & 1.84 & 1.62 \\
\hline DBCover & 12 & 0 & 25 & 14 & 15 & 4.8 & 14 & 14 & 13 & 7.7 \\
\hline Nactive & 105 & 10 & 3 & 23 & 62 & 6 & 1 & - & 73 & 32 \\
\hline \%active & 54 & 53 & 100 & 100 & 72 & 26 & 2 & - & 55 & 51 \\
\hline Aspect & N/NE & - & $\mathrm{N}$ & N/NE & NE & $\mathrm{N}$ & N/NE & N/NE & N/NE & NE/E \\
\hline
\end{tabular}




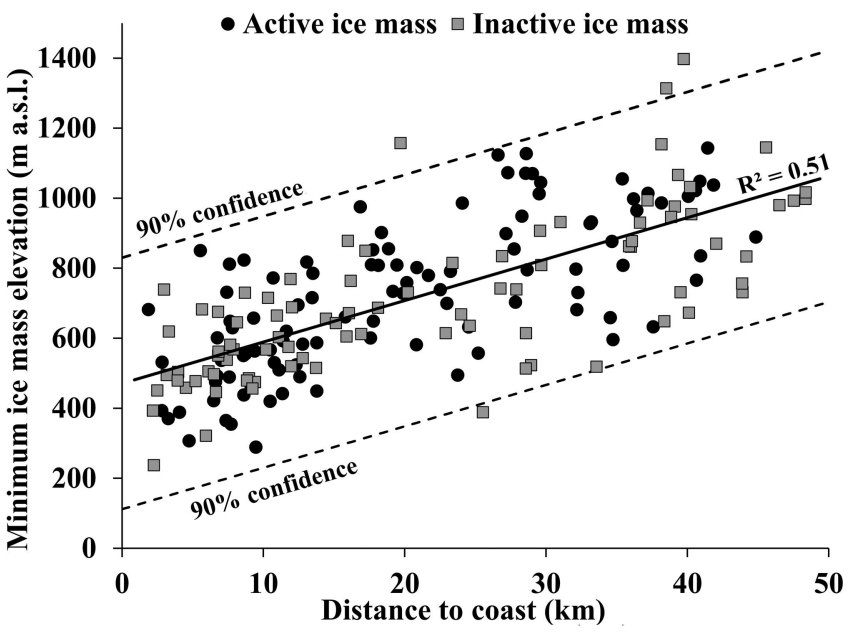

Fig. 6. Scatter plot of minimum elevation and distance from the Labrador Sea coastline for each of the Torngat ice masses. Black dots and grey squares represent active and inactive ice masses, respectively. Least-squares regression line is shown with the $90 \%$ confidence interval for lower and upper bounds.

minimum elevation of Torngat ice masses (Fig. 6), with increasingly elevated ice mass snouts farther inland ( $\sim 12 \mathrm{~m} \mathrm{~km}^{-1}$ with distance from the coast). Consistent with this trend is the statistically significant difference $(99 \% \mathrm{CL})$ between the elevations of ice mass snouts in the fretted mountains and interior plateau (Table 1). Significant differences are also observed between the mean elevations of topographically shadowed ice mass forms (e.g. niche and remnant) and less shadowed ice masses (e.g. simple basin and summit) (Table 1; Fig. 7).

Most Torngat ice masses have a northerly aspect (63\%), with the majority facing either north $(23 \%)$ or northeast $(28 \%)$. Ice masses rarely have a southerly aspect $(11 \%)$, and even fewer are west-facing (5\%). Summit, simple basin and cirque ice masses typically are more compact than niche and remnant ice masses (Table 1 ).

\section{Topographic setting}

Torngat ice masses had a median back-wall height of $227 \mathrm{~m}$ with an interquartile range of $148-296 \mathrm{~m}$ (Table 1). Ice masses in the fretted mountains had higher back-walls (medians 250 vs $170 \mathrm{ma.s.l}$.) and total upslope areas (medians 0.17 vs $0.10 \mathrm{~km}^{2}$ ) compared to those in the interior plateau, reflecting the relatively greater relief of the coastal mountains. Most ice mass forms in the region had a relative upslope area between 1.09 and 1.86, with the exception of remnant ice masses that had higher values (median 3.32; Table 1) and summit ice masses, which by definition had no relative upslope area (Table 1). Summit ice

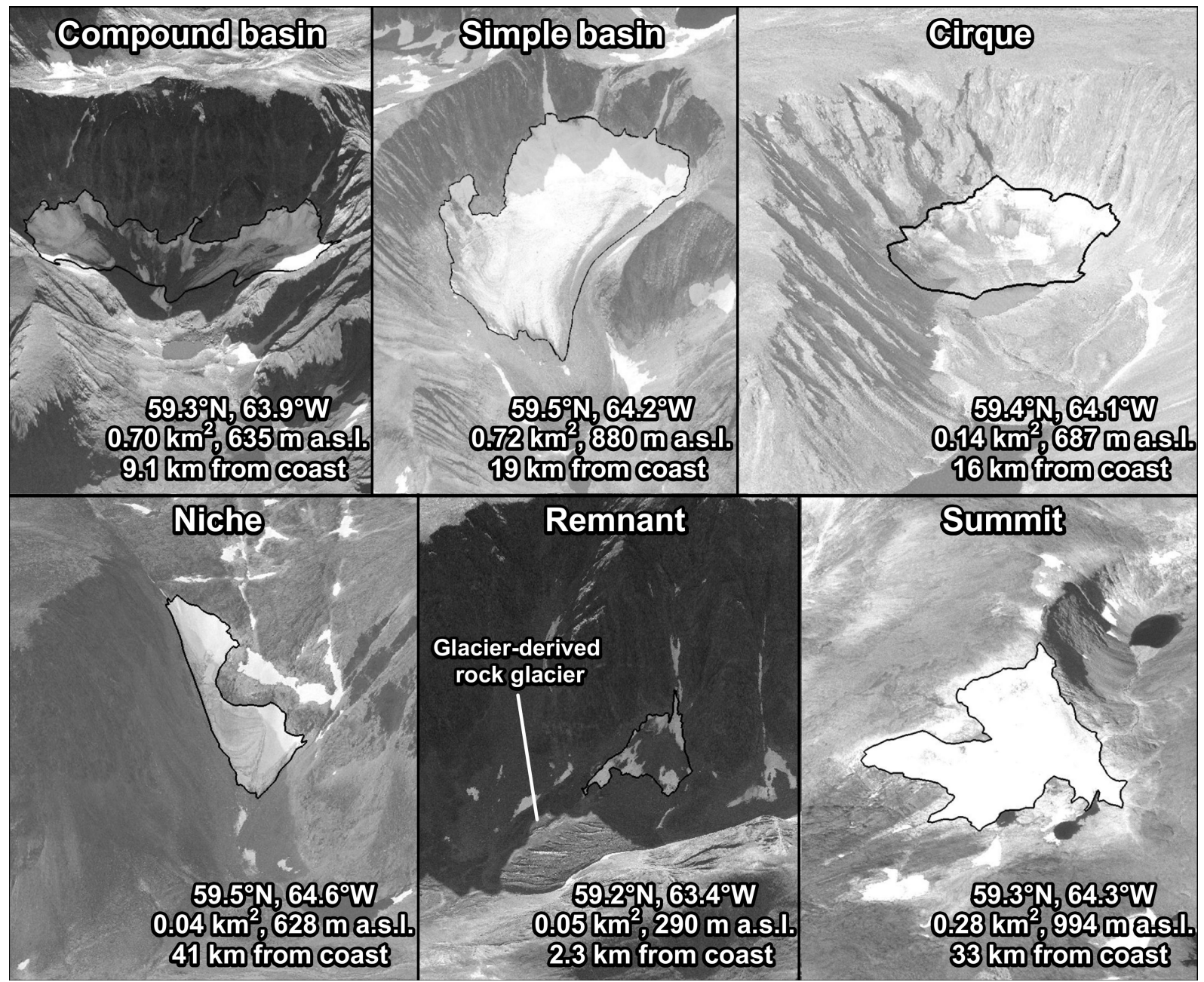

Fig. 7. Examples of each of the six ice mass forms classified in the Torngat Mountains using GLIMS classification procedures. Images are derived from aerial photographs overlain on a DEM with black outlines depicting 2005 ice mass margins. Dialog boxes contain latitude $\left({ }^{\circ} \mathrm{N}\right)$, longitude $\left({ }^{\circ} \mathrm{W}\right)$, total area in $2005\left(\mathrm{~km}^{2}\right)$, mean elevation (ma.s.I.) and the distance from the Labrador Sea coastline (km) for each ice mass. 
masses had the greatest incoming solar radiation due to their relatively exposed surfaces, whereas remnant ice masses had the smallest values (Fig. 8). The results of the Spearman correlation analysis show ice mass area is negatively correlated with both mean slope and relative upslope area (Table 2). Neither result is surprising given that the smallest Torngat ice masses are typically found adhering to steep mountainsides or large cirque back-walls and the largest ice masses flow into flatter basins and valleys. Likewise, ice mass length is negatively correlated with mean slope for the same reason. Upslope area is shown to be strongly positively correlated with total ice mass area while negative correlations are found between incoming solar radiation and ice mass slope (Table 2). Statistical associations between solar radiation and three topographic parameters (contributing area slope, back-wall height, relative upslope area) suggest that ice masses receiving less solar radiation have large, steep back-walls. Incoming solar radiation is also positively correlated with ice mass elevation, implying that more exposed surfaces were found higher in the mountains while the lowest ice masses are more topographically protected (Table 2). A relation with elevation is also reflected in the classification of ice form (Fig. 8).

\section{Active glaciers}

In this study, $54 \%$ of ice masses showed evidence of actively flowing ice, the majority as either cirques $(n=62)$ or simple and compound basin forms $(n=26)$. Actively flowing glaciers made up $\sim 20 \mathrm{~km}^{2}$ or $81 \%$ of the total ice area, and $70 \%$ of them were in the fretted coastal mountains. A similar proportion of active glaciers faced north or northeast compared to the total glacier population. Statistically significant differences between active and inactive ice masses were apparent for many variables including compactness $(99 \% \mathrm{CL})$, debris cover $(99 \% \mathrm{CL})$, elevation $(99 \%$ $\mathrm{CL})$, latitude $(93 \% \mathrm{CL})$, length $(99 \% \mathrm{CL})$, relative upslope area $(99 \% \mathrm{CL})$, size $(99 \% \mathrm{CL})$, slope $(99 \% \mathrm{CL})$ and solar radiation $(92 \% \mathrm{CL})$. Relative to inactive ice masses, median values show that active glaciers were typically larger,

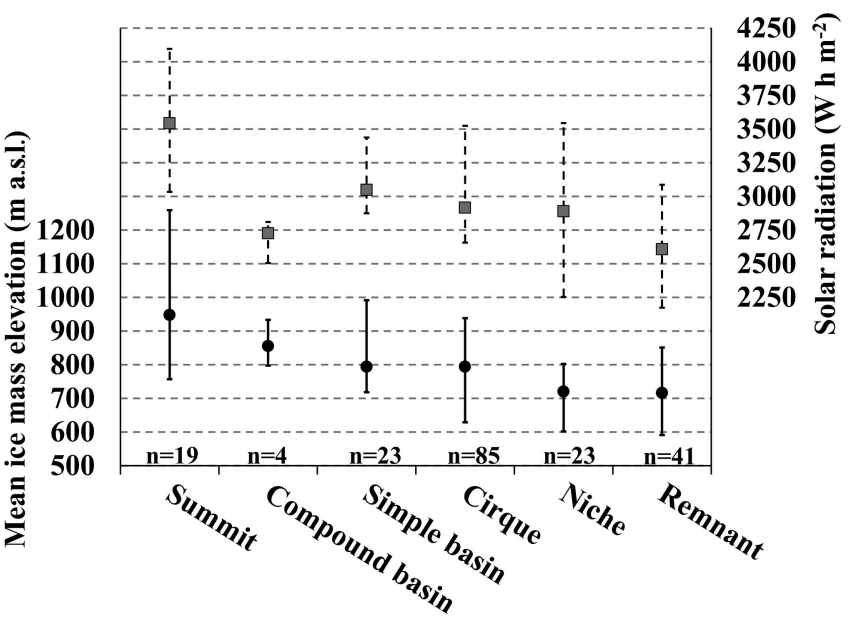

Fig. 8. Relation between ice mass form, median ice mass elevation (circles) and median incoming solar radiation (squares). Vertical lines show the interquartile range.

longer, more compact, slightly more northerly, higher and more debris-covered (Table 1). On average, active glaciers also had lower slopes, smaller relative upslope areas and correspondingly higher incoming solar radiation. A few variables (e.g. back-wall height and contributing area slope) showed no statistically significant differences between active and inactive ice masses.

\section{DISCUSSION}

\section{Torngat ice masses in local context}

Our study reveals several distinct patterns in the general characteristics and geographic distribution of ice masses in the Torngat Mountains. First, most Torngat ice masses exist in topographically protected basins with the largest ice masses (simple and compound basin) almost exclusively originating in cirques with large back-walls (Fig. 8). Second, active ice masses occur at higher elevations and farther

Table 2. Spearman rho rank correlation matrix between geographic, topographic and morphometric parameters for ice masses in the Torngat glacier inventory. Table presents correlations ( $r_{\mathrm{s}}$ values) for individual ice mass area (Area; $\mathrm{km}^{2}$ ), incoming solar radiation (Solar; $\mathrm{W} \mathrm{h} \mathrm{m}^{-2}$ ), ice mass latitude (Lat; ${ }^{\circ} \mathrm{N}$ ), minimum elevation (MinElev-MnElev; m a.s.I.), maximum elevation (MaxElev-MxElev; m a.s.I.), mean elevation (MeanElev-MeElev; ma.s.I.), ice mass slope (Slope; ${ }^{\circ}$ ), distance to coastline (D2Coast; km), total upslope area $\left(\right.$ UpArea; $\mathrm{km}^{2}$ ), contributing area slope (CASlope-CAS; ${ }^{\circ}$ ), ice mass length (Length; km), mean back-wall height $(\mathrm{BWH} ; \mathrm{m})$, relative upslope area (RelUARUA; ratio), compactness (Compact; undefined) and debris cover (DBCover; \%). Only statistically significant correlations ( $>95 \% \mathrm{CL}$ (confidence level)) are shown

\begin{tabular}{|c|c|c|c|c|c|c|c|c|c|c|c|c|}
\hline Indices & Area & Solar & Lat & MnElev & MxElev & MeElev & Slope & UpArea & CAS & Length & BWH & RUA \\
\hline Solar & 0.29 & - & - & - & - & - & - & - & - & - & - & - \\
\hline MaxElev & 0.27 & 0.28 & -0.32 & - & - & - & - & - & - & - & - & - \\
\hline MeanElev & - & 0.32 & -0.32 & - & - & - & - & - & - & - & - & - \\
\hline Slope & -0.65 & -0.45 & - & - & - & - & - & - & - & - & - & - \\
\hline UpArea & 0.59 & - & - & - & - & - & -0.26 & - & - & - & - & - \\
\hline CASlope & - & -0.49 & - & -0.35 & -0.32 & -0.36 & 0.26 & 0.24 & - & - & - & - \\
\hline Length & 0.83 & 0.25 & - & - & 0.28 & - & -0.62 & 0.45 & - & - & - & - \\
\hline BWH & - & -0.30 & - & -0.37 & -0.30 & -0.35 & - & 0.66 & 0.66 & - & - & - \\
\hline RelUA & -0.42 & -0.38 & - & - & - & - & 0.45 & 0.40 & 0.39 & -0.44 & 0.64 & - \\
\hline Compact & 0.29 & - & - & - & - & - & - & - & - & 0.42 & - & -0.33 \\
\hline DBCover & - & -0.32 & - & - & - & - & - & 0.33 & 0.39 & - & 0.33 & - \\
\hline
\end{tabular}


north, where melt seasons are presumably shorter and less intense (DeBeer and Sharp, 2009). Third, active ice masses are also more heavily debris-covered than inactive ice masses, further reducing melt rates (Rogerson and others, 1986b). By contrast, inactive ice masses are more reliant on snow avalanching as indicated by large relative upslope areas and reduced melt rates due to topographic shadowing. Fourth, the ice-mass forms characterized by the most topographic shadowing (cirque, niche and remnant) are more numerous and receive less incoming radiation, thereby demonstrating the importance of local topography for ice preservation (Table 1). The steep upslope contributing areas on most Torngat ice masses are also important for avalanching snow onto ice surfaces, with most Torngat ice masses having upslope areas that are larger than the ice masses themselves (Rogerson and others, 1986a). By contrast, summit ice masses, which lack protection from local topography and have no upslope area, receive more solar radiation and have higher elevation values, making their presence indicative of the true regional snowline in the interior (Fig. 8) (Wolken and others, 2008). The more frequent occurrence of Torngat ice masses in the fretted coast relative to the inland plateau seems to be related to regional physiography. In particular, the fretted landscape of the coastal Torngat Mountains is more dissected than the inland plateau, increasing the frequency of cirque and niche topographic settings near the coastline. The inland Torngat Mountains, though consisting of high overall elevations, are dominated by extensive plateau landscapes that provide minimal topographic protection from solar radiation and fewer niches for snow accumulation. The plateau is therefore less likely to sustain small mountain glaciers but more likely to contain larger plateau ice masses when a drop in the regional glaciation level occurs (Rea and others, 1998). This is reflected in the inventory data showing that coastal ice masses are typically larger, longer and more active than those in the interior plateau.

Ice masses in the fretted coast also have substantially lower ice elevations, with distance to the Labrador Sea coastline being the strongest predictor of all ice mass elevation parameters. The influence of maritime meteorological conditions on near-coast ice masses may explain some of this association. For example, summer fog has been shown to protect glaciers from intense summer melt by reflecting incoming solar radiation and by providing additional moisture close to ice masses (e.g. Mernild and others, 2008; Jiskoot and others, 2012). The pattern of dense fog and low-level cloud during the summertime in the coastal Torngat Mountains (Maxwell, 1981) supports this hypothesis. In the complex topography of the coastal Torngat Mountains, it is difficult to assess the importance of prevailing winds on snow redistribution and corresponding ice mass location. Inland along the plateau, however, ice masses predominantly face east to northeast, enhancing lee-side accumulation of snow on ice surfaces from westerly winds.

Ice mass characteristics, particularly ice mass elevation, were also found to be related to several topographic factors (e.g. CASlope, BWH, RelUA). These results suggest that ice masses with lower elevations are more reliant on mass input from avalanching potentially causing more ice flux through their equilibrium-line altitudes. The low compactness values found for niche and remnant ice masses reflect irregularshaped ice masses fed through avalanching (DeBeer and Sharp, 2009). Given that local topography is an important factor for Torngat ice masses, it might be expected that regional geology is associated with several topographic variables (e.g. back-wall height, contributing area slope, debris cover and relative upslope area). However, examining the spatial distribution of these variables shows consistent results across the various rock types in the Torngat Mountains (e.g. Wardle and others, 1997). To further evaluate the importance of regional geology, we examined the distribution of mean ice mass elevation for each rock type after the influences of distance to coast and latitude had been removed with multiple regression $\left(\operatorname{adj} R^{2}=0.49\right)$. Iterative $t$-tests showed that the residuals from the regression model had little spatial structure and are statistically indistinguishable across the major rock types, suggesting that regional geology is largely unrelated to ice mass distribution and elevation.

\section{Torngat ice masses in regional perspective}

The ice masses of the Torngat Mountains are on average the smallest ice masses inventoried in the Canadian Arctic and contain far less ice than other glacier populations (Sharp and others, 2011b). Relative to their latitude they exist considerably lower in the mountains than many other mountain glaciers, particularly those in the Canadian Rockies, Swiss Alps and Scandinavia (Paul and others, 2004; Paul and Andreassen, 2009; Andreassen and Winsvold, 2012; Tennant and others, 2012). However, the most maritime glaciers in Iceland, coastal Norway and the coastal Rocky Mountains exist at similar elevations (Nesje and others, 2008; Huss and Farinotti, 2012). Glacier inventories completed on small glaciers in southern Baffin Island $\left(64-68^{\circ} \mathrm{N}\right)$ and the Ural Mountains $\left(64-68^{\circ} \mathrm{N}\right)$ have similar median elevations to those in the Torngat Mountains (e.g. Paul and Kääb, 2005; Paul and Svoboda, 2009; Svoboda and Paul, 2009), with the latter glaciers also being similar in size, morphometry and topographic setting (Kononov and others, 2005; Shahgedanova and others, 2012).

Many authors have observed that local topographic setting has a strong influence on small glaciers in alpine environments (Kuhn, 1995; Hoffman and others, 2007; DeBeer and Sharp, 2009) and that some small topographically protected glaciers have exhibited less recent change than nearby glaciers (e.g. DeBeer and Sharp, 2009; Basagic and Fountain, 2011; Li and others, 2011; Stokes and others, 2013). Federici and Pappalardo (2010) and Shahgedanova and others (2012) also noted that the recession of some small glaciers slowed once they receded into the most protected portions of their shadowed cirques where they receive less direct radiation. Likewise, in the Torngat Mountains most ice masses historically extended beyond their protective basins, but since have retreated up-valley into their cirques where large back-walls protect ice surfaces from incoming solar radiation (e.g. DeBeer and Sharp, 2009). The importance of high back-walls for debris transport onto Torngat ice surfaces is another relevant consideration (e.g. Stokes and others, 2013) given that there are direct observations of decreased melting on debris-covered Torngat glaciers (Rogerson and others, 1986a). Although topographic setting influences the distribution of ice masses in the Torngat Mountains, the presence of summit ice masses at lower elevations than similar features much farther north in western Scandinavia suggests that other factors (e.g. maritime conditions) are also relevant (Manley, 1955; Gellatly and others, 1988; Rea and Evans, 2007). 
Table 3. Comparison between the full Torngat ice mass inventory (excluding subset) and the ice masses of the Blow Me Down Mountains (BMD) and Mount Razorback (MR) which are investigated separately

\begin{tabular}{lcc}
\hline Variable/dataset & Full & BMD and MR \\
\hline Count (No.) & 168 & 27 \\
Area $\left(\mathrm{km}^{2}\right)$ & 0.08 & 0.08 \\
Latitude $\left({ }^{\circ} \mathrm{N}\right)$ & 59.2 & 58.8 \\
Elevation (m a.s.l.) & 815 & 585 \\
Distance to coast $(\mathrm{km})$ & 22.1 & 6.5 \\
Debris cover $(\%)$ & 11.8 & 17.2 \\
Back-wall height $(\mathrm{m})$ & 221 & 244 \\
Relative upslope area & 1.74 & 2.02 \\
Solar $\left(\mathrm{W} \mathrm{h} \mathrm{m}{ }^{-2}\right)$ & 3076 & 2770
\end{tabular}

Maritime conditions and coastal proximity have been shown to influence (reduce) glacier elevations in many regions (e.g. Nesje and others, 2008; Huss and Farinotti, 2012; Jiskoot and others, 2012). For example, the most coastal glacier ranges in southwestern and northern Norway contain the glaciers with the lowest elevations while the mountain glaciers further inland are typically restricted to the uppermost mountains (Gellatly and others, 1988; Andreassen and Winsvold, 2012). Maritime influences can also be seen when examining long-term glacier changes in southwest Norway where coastal glaciers notably advanced during the 1990s in response to increased winter snowfall while continental glaciers showed little change (Chinn and others, 2005). Likewise, in the Canadian Cordillera, coastal glaciers were found to be less sensitive to ablation-season temperature changes than their interior counterparts, possibly due to maritime conditions (Schiefer and Menounos, 2010). In many of these maritime environments the survival of mountain glaciers at low elevations is due to heavy winter precipitation (e.g. Nesje and others, 2008). However, in the Torngat Mountains the combined effects of local topographic setting and coastal meteorological conditions explain ice mass formation at lower elevations than other mid-latitude glaciers, similar to Ural Mountains glaciers which have local conditions that favor snow accumulation in cirques (Kononov and others, 2005; Solomina and others, 2010).

\section{Regional glacierization level}

Visual examination of the relation between latitude and ice mass elevation reveals a group of low-elevation outlier ice masses impacting the least-squares fit. These ice masses are exclusively found in the coastal ranges of the Blow Me Down Mountains (BMD) and on the coastal side of Mount Razorback (MR). Further inspection of these ice masses reveals that they exist in topographically unique settings with unusually high, steep back-walls relative to other Torngat ice masses (Table 3). They are also characteristically more heavily debris-covered, possibly due to their larger upslope contributing areas. In addition to these topographic factors, the BMD and MR ice masses exist in close proximity to the Labrador Sea (all within $10 \mathrm{~km}$ of the coastline), presumably reflecting the importance of local meteorological conditions. Given that these ice masses exist in a unique topographic and geographic setting, they are unlikely to be representative of the conditions experienced for most of the Torngat

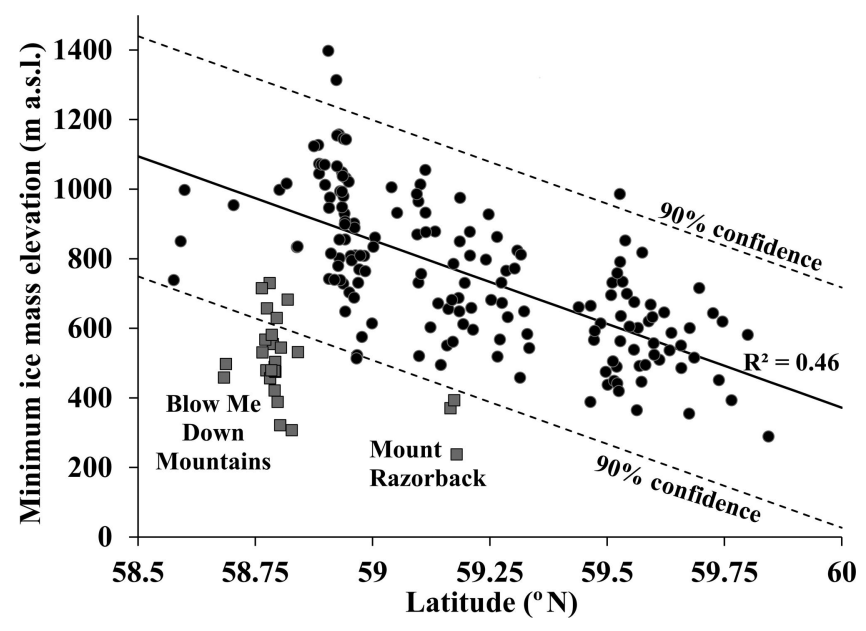

Fig. 9. Scatter plot of latitude and minimum elevation for ice masses (dots; $n=168$ ) in the Torngat Mountains. Ice masses from the Blow Me Down Mountains and Mount Razorback are represented by grey squares $(n=27)$. A least-squares regression line (solid) is shown with $90 \%$ confidence intervals (dashed) for glaciers (black dots) other than those in the Blow Me Down Mountains and Mount Razorback.

glaciers. By excluding these two regions, a much stronger relationship is found between ice mass elevation and latitude $\left(r^{2}=0.47\right)$, with the slope of the regression line interpreted as the mean elevation of topographically advantaged mountain glaciers (Fig. 9). Using only ice masses classified as active this relationship is even stronger $\left(r^{2}=0.57\right)$. Examination of ice masses with the least topographic influence (summit ice masses) shows that the regression line presented in Figure 9 is a good approximation for the minimum regional glacierization level in the Torngat Mountains.

\section{Challenges of classification and inventorying}

Most ice masses in the Torngat Mountains are small $\left(0.1 \mathrm{~km}^{2}\right)$, making them difficult to map on mediumresolution satellite imagery such as Landsat and ASTER. Using high-resolution imagery can increase the accuracy for mapping small ice masses; however, the cost of acquiring aerial photography or satellite imagery at high spatial resolution can be prohibitive, particularly for monitoring purposes. Pronounced topographic shadowing in the highrelief Torngat Mountains also made the process of delineating and classifying ice mass margins difficult and timeconsuming (e.g. Stokes and others, 2013). In some cases, shadowing may have hindered the identification of bare glacier ice and evidence of glacier flow (e.g. flowlines and crevasses). Shadowing deep in cirques may also have affected the differentiation between perennial snow and ice. Widespread debris cover on many Torngat ice masses, particularly when concentrated at lower ice elevations, may have resulted in some underestimation of ice mass size. Furthermore, medial moraines, debris ridges and thick icecored debris fields in the foregrounds of many Torngat ice masses complicated the delineation of the boundaries between active and inactive debris-covered ice (Racoviteanu and others, 2010; Paul and others, 2013). Additionally, snowpatches on late-summer aerial photographs introduced challenges for mapping precise ice margins and potentially obscured evidence of ice flow that might otherwise have been visible during summers with limited snow cover (Racoviteanu and others, 2009; Stokes and others, 2013). 


\section{CONCLUSION}

In this study, we have conducted the first complete inventory of ice masses in the Torngat Mountains of northern Labrador. In total, there are 195 Torngat ice masses, with the majority being actively flowing small mountain glaciers. All Torngat ice masses are located within $50 \mathrm{~km}$ of the coastline, where a combination of regional physiography and local meteorological conditions favor ice preservation. The topographic setting of ice masses is characterized by high back-walls, heavy debris cover and topographic shadowing. Torngat ice masses have mean elevations below other low-Arctic glaciers and occur farther south than expected based on latitude alone. We propose that unique topographical and meteorological conditions explain much of this discrepancy. By examining classification and topographic setting parameters, the data suggest that low-altitude ice masses are able to survive because of protection from solar radiation given by high back-walls and sometimes heavy debris cover. Distance to the Labrador coastline is found to be the best predictor of ice mass elevation, suggesting that local meteorological conditions may play a role in preserving ice masses in near-coastal environments. By excluding ice masses from two nearcoastal sites that have unique topographic and meteorological settings (Blow Me Down Mountains and Mount Razorback), a regional glacierization level can be estimated.

\section{ACKNOWLEDGEMENTS}

We acknowledge the Torngat Mountains base camp and research station (kANGIDLUASUk), Parks Canada and Arctic Net for logistical support in the Torngat Mountains. A special thanks to our bear monitor Andreas Tuglivina and to field assistants Jodie Chadbourn, Philippe Leblanc, Svieda Mah and Alexandre Melanson. Digital elevation and remotesensing data were provided by Parks Canada. Funding and in-kind support from ArcticNet, the Nunatsiavut Government, Memorial University of Newfoundland, the Natural Science and Engineering Research Council of Canada, the Northern Scientific Training Program and the W. Garfield Weston Foundation made this project possible. The paper benefited from discussions with or comments by Angus Simpson, Darroch Whitaker, Bob Rogerson, David Evans, Joel Finnis, Philippe Leblanc and two anonymous reviewers.

\section{REFERENCES}

Anderson RK, Miller GH, Briner JP, Lifton NA and DeVogel SB (2008) A millennial perspective on Arctic warming from $14 \mathrm{C}$ in quartz and plants emerging from beneath ice caps. Geophys. Res. Lett., 35(1), L01502 (doi: 10.1029/2007GL032057)

Andreassen LM and Winsvold SH eds. (2012) Inventory of Norwegian glaciers. NVE Report 38-2012

Arendt A and 77 others (2013) Randolph Glacier Inventory - a dataset of global glacier outlines: version 3.2. Global Land Ice Measurements from Space, Boulder, CO. Digital media: http:// www.glims.org/RGI/randolph.html

Banfield CE and Jacobs JD (1998) Regional patterns of temperature and precipitation for Newfoundland and Labrador during the past century. Can. Geogr., 42(4), 354-364 (doi: 10.1111/j.15410064.1998.tb01351.x)

Barrand NE and Sharp MJ (2010) Sustained rapid shrinkage of Yukon glaciers since the 1957-1958 International Geophysical Year. Geophys. Res. Lett., 37(L7), L07051 (doi: 10.1029/ 2009GL042030)
Basagic HJ and Fountain AG (2011) Quantifying 20th Century glacier change in the Sierra Nevada, California. Arct. Antarct. Alp. Res., 43(3), 317-330 (doi: 10.1657/1938-4246-43.3.317)

Benn DI and Evans DJA (2010) Glaciers and glaciation, 2nd edn. Hodder Education, London

Benoit R and 20 others (2002) The real-time ultrafinescale forecast support during the special observing period of the MAP. Bull. Am. Meteorol. Soc., 83(1), 85-109 (doi: 10.1175/1520-0477 (2002)083<0085:TRTUFS $>2.3 . \mathrm{CO} ; 2)$

Bishop MP and 16 others (2004) Global land ice measurements from space (GLIMS): remote sensing and GIS investigations of the Earth's cryosphere. Geocarto Int., 19(2), 57-84 (doi: 10.1080/10106040408542307)

Bolch T, Menounos B and Wheate R (2010) Landsat-based inventory of glaciers in western Canada, 1985-2005. Remote Sens. Environ., 114(1), 127-137 (doi: 10.1016/j.rse.2009.08.015)

Bostock HS (1970) Physiographic regions of Canada, 1:5,000 000. Geological Survey of Canada, Ottawa, Ont.

Brown BR and 15 others (2012) Climate variability and change in the Canadian Eastern Subarctic IRIS region (Nunavik and Nunatsiavut). In Allard $M$ and Lemay $M$ eds. Nunavik and Nunatsiavut: from science to policy. An Integrated Regional Impact Study (IRIS) of climate change and modernization. ArcticNet, Université Laval, Quebec, Que.

Chinn T, Winkler S, Salinger MJ and Haakensen N (2005) Recent glacier advances in Norway and New Zealand: a comparison of their glaciological and meteorological causes. Geogr. Ann. A, 87(1), 141-157 (doi: 10.1111/j.0435-3676.2005.00249.x)

Church JA and White NJ (2011) Sea-level rise from the late 19th to the early 21st Century. Surv. Geophys., 32(4-5), 585-602 (doi: 10.1007/s10712-011-9119-1)

Clark PU (1991) Landscapes of glacial erosion, Torngat Mountains, northern Labrador/Ungava. Can. Geogr., 35(2), 208-213 (doi: 10.1111/j.1541-0064.1991.tb01293.x)

Conover WJ (1999) Practical nonparametric statistics. Wiley, New York

Cowtan K and Way RG (2014) Coverage bias in the HadCRUT4 temperature series and its impact on recent temperature trends. Q. J. R. Meteorol. Soc., 140(683), 1935-1944 (doi: 10.1002/qj.2297)

Davies BJ and Glasser NF (2012) Accelerating shrinkage of Patagonian glaciers from the Little Ice Age ( AD 1870) to 2011. J. Glaciol., 58(212), 1063-1084 (doi: 10.3189/2012JoG12J026)

DeBeer CM and Sharp MJ (2009) Topographic influences on recent changes of very small glaciers in the Monashee Mountains, British Columbia, Canada. J. Glaciol., 55(192), 691-700 (doi: 10.3189/002214309789470851)

Dee DP and 35 others (2011) The ERA-Interim reanalysis: configuration and performance of the data assimilation system. Q. J. R. Meteorol. Soc., 137(656), 553-597 (doi: 10.1002/qj.828)

Federici PR and Pappalardo $M$ (2010) Glacier retreat in the Maritime Alps area. Geogr. Ann. A, 92(3), 361-373 (doi: 10.1111/j.1468-0459.2010.00401.x)

Fisher D and 6 others (2012) Recent melt rates of Canadian Arctic ice caps are the highest in four millennia. Global Planet. Change, 84-85, 3-7 (doi: 10.1016/j.gloplacha. 2011.06.005)

Forbes A, Miller OM, Odell NE and Abbe EC (1938) Northernmost Labrador mapped from the air. (AGS Special Publication 22) American Geographical Society, New York

Frey-Buness F, Heimann D and Sausen R (1995) A statisticaldynamical downscaling procedure for global climate simulations. Theor. Appl. Climatol., 50(3-4), 117-131 (doi: 10.1007/ BF00866111)

Fu P and Rich PM (2002) A geometric solar radiation model with applications in agriculture and forestry. Comput. Electron. Agr., 37(1-3), 25-35 (doi: 10.1016/S0168-1699(02)00115-1)

Gardner AS and 15 others (2013) A reconciled estimate of glacier contributions to sea level rise: 2003 to 2009. Science, 340(6134), 852-857 (doi: 10.1126/science.1234532) 
Gellatly AF, Gordon JE, Whalley WB and Hansom JD (1988) Thermal regime and geomorphology of plateau ice caps in northern Norway: observations and implications. Geology, 16(11), 983-986 (doi: 10.1130/0091-7613(1988)016<0983: TRAGOP>2.3.CO;2)

Granshaw FD and Fountain AG (2006) Glacier change (19581998) in the North Cascades National Park Complex, Washington, USA. J. Glaciol., 52(177), 251-256 (doi: 10.3189/ 172756506781828782)

Henoch WES and Stanley AD. (1968) Glacier map of southern Baffin Island (District of Franklin) and northern Labrador Peninsula (Quebec and Newfoundland) 1:1000000. Glacier Maps of Canada Glaciology Subdivision, Inland Waters Branch, Department of Energy, Mines and Resources, Ottawa, Ont.

Hoffman MJ, Fountain AG and Achuff JM (2007) 20th-century variations in area of cirque glaciers and glacierets, Rocky Mountain National Park, Rocky Mountains, Colorado, USA. Ann. Glaciol., 46, 349-354 (doi: 10.3189/172756407782871233)

Huss M and Farinotti D (2012) Distributed ice thickness and volume of all glaciers around the globe. J. Geophys. Res., 117(F4), F04010 (doi: 10.1029/2012JF002523)

Jiskoot H, Juhlin D, St Pierre H and Citterio M (2012) Tidewater glacier fluctuations in central East Greenland coastal and fjord regions (1980s-2005). Ann. Glaciol., 53(60 Pt 1), 35-44 (doi: 10.3189/2012AoG60A030)

Kääb A (2005) Remote sensing of mountain glaciers and permafrost creep. (Schriftenreihe Physische Geographie Glaziologie und Geomorphodynamik 48) Geographisches Institut der Universität Zürich, Zürich

Kääb A, Paul F, Maisch M, Hoelzle M and Haeberli W (2002) The new remote-sensing-derived Swiss glacier inventory: II. First results. Ann. Glaciol., 34, 362-366 (doi: 10.3189/ 172756402781817473)

Knoll C, Kerschner H, Heller A and Rastner P (2009) A GIS-based reconstruction of Little Ice Age glacier maximum extents for South Tyrol, Italy. Trans. GIS, 13(5-6), 449-463 (doi: 10.1111/ j.1467-9671.2009.01173.x)

Kononov YM, Ananicheva MD and Willis IC (2005) Highresolution reconstruction of Polar Ural glacier mass balance for the last millennium. Ann. Glaciol., 42, 163-170 (doi: 10.3189/172756405781812709)

Kottek M, Grieser J, Beck C, Rudolf B and Rubel F (2006) World map of the Köppen-Geiger climate classification updated. Meteorol. Z., 15(3), 259-263 (doi: 10.1127/0941-2948/2006/0130)

Kuhn M (1995) The mass balance of very small glaciers. Z. Gletscherkd. Glazialgeol., 31(1-2), 171-179

Li K, Li H, Wang L and Gao W (2011) On the relationship between local topography and small glacier change under climatic warming on Mt. Bogda, eastern Tian Shan, China. J. Earth Sci., 22(4), 515-527 (doi: 10.1007/s12583-011-0204-7)

Lindsay R, Wensnahan M, Schweiger A and Zhang J (2014) Evaluation of seven different atmospheric reanalysis products in the Arctic. J. Climate, 27(7), 2588-2606 (doi: 10.1175/JCLI-D13-00014.1)

Manley G (1955) On the occurrence of ice domes and permanently snow-covered summits. J. Glaciol., 2(17), 453-456 (doi: 10.3189/002214355793702244)

Mann PS (2007) Introductory statistics. Wiley, Hoboken, NY

Marquette GC and 6 others (2004) Felsenmeer persistence under non-erosive ice in the Torngat and Kaumajet mountains, Quebec and Labrador, as determined by soil weathering and cosmogenic nuclide exposure dating. Can. J. Earth Sci., 41(1), 19-38 (doi: 10.1139/e03-072)

Marsaglia G, Tsang WW and Wang J (2003) Evaluating Kolmogorov's Distribution. J. Stat. Softw., 8(18), 1-4

Maxwell JB (1981) Climatic regions of the Canadian Arctic Islands. Arctic, 34(3), 225-240 (doi: 10.14430/arctic2525)

McCoy WD (1983) Holocene glacier fluctuations in the Torngat Mountains, northern Labrador. Géogr. Phys. Quat., 37(2), 211-216 (doi: 10.7202/032516ar)
Meier MF (1984) Contribution of small glaciers to global sea level. Science, 226(4681), 1418-1421 (doi: 10.1126/science. 226.4681.1418)

Meier MF and 7 others (2007) Glaciers dominate eustatic sea-level rise in the 21st century. Science, 317(5841), 1064-1067 (doi: 10.1126/science.1143906)

Mernild SH, Kane DL, Hansen BU, Jakobsen BH, Hasholt B and Knudsen NT (2008) Climate, glacier mass balance and runoff (1993-2005) for the Mittivakkat Glacier catchment, Ammassalik Island, SE Greenland, and in a long term perspective (18981993). Hydrol. Res., 39(4), 239-256 (doi: 10.2166/nh.2008.101)

Metzger MJ, Bunce RGH, Jongman RHG, Sayre R, Trabucco A and Zomer R (2013) A high-resolution bioclimate map of the world: a unifying framework for global biodiversity research and monitoring. Global Ecol. Biogeogr., 22(5), 630-638 (doi: 10.1111/geb.12022)

Nesje A, Bakke J, Dahl SO, Lie Ø and Matthews JA (2008) Norwegian mountain glaciers in the past, present and future. Global Planet. Change, 60(1-2), 10-27 (doi: 10.1016/j.gloplacha.2006.08.004)

Odell NE (1933) The mountains of northern Labrador. Geogr. J., 82(3), 193-210 (doi: 10.2307/1786557)

Pan BT and 7 others (2012) Glacier changes from 1966-2009 in the Gongga Mountains, on the south-eastern margin of the QinghaiTibetan Plateau and their climatic forcing. Cryosphere, 6(5), 1087-1101 (doi: 10.5194/tc-6-1087-2012)

Paul F and Andreassen LM (2009) A new glacier inventory for the Svartisen region, Norway, from Landsat ETM+ data: challenges and change assessment. J. Glaciol., 55(192), 607-618 (doi: 10.3189/002214309789471003)

Paul F and Kääb A (2005) Perspectives on the production of a glacier inventory from multispectral satellite data in Arctic Canada: Cumberland Peninsula, Baffin Island. Ann. Glaciol., 42, 59-66 (doi: 10.3189/172756405781813087)

Paul F and Svoboda F (2009) A new glacier inventory on southern Baffin Island, Canada, from ASTER data: II. Data analysis, glacier change and applications. Ann. Glaciol., 50(53), 22-31 (doi: 10.3189/172756410790595921)

Paul F, Kääb A, Maisch M, Kellenberger T and Haeberli W (2004) Rapid disintegration of Alpine glaciers observed with satellite data. Geophys. Res. Lett., 31(21), L21402 (doi: 10.1029/ 2004GL020816)

Paul F and 9 others (2009) Recommendations for the compilation of glacier inventory data from digital sources. Ann. Glaciol., 50(53), 119-126 (doi: 10.3189/172756410790595778)

Paul F and 19 others (2013) On the accuracy of glacier outlines derived from remote-sensing data. Ann. Glaciol., 54(63 Pt 1), 171-182 (doi: 10.3189/2013AoG63A296)

Pellikka P and Rees WG (2009) Remote sensing of glaciers: techniques for topographic, spatial and thematic mapping of glaciers. Taylor and Francis, London

Racoviteanu AE, Paul F, Raup B, Khalsa SJS and Armstrong R (2009) Challenges and recommendations in mapping of glacier parameters from space: results of the 2008 Global Land Ice Measurements from Space (GLIMS) workshop, Boulder, Colorado, USA. Ann. Glaciol., 50(53), 53-69 (doi: 10.3189/ 172756410790595804)

Radić V and Hock R (2011) Regionally differentiated contribution of mountain glaciers and ice caps to future sea-level rise. Nature Geosci., 4(2), 91-94 (doi: 10.1038/ngeo1052)

Radić V, Bliss A, Beedlow AC, Hock R, Miles E and Cogley JG (2014) Regional and global projections of twenty-first century glacier mass changes in response to climate scenarios from global climate models. Climate Dyn., 42(1-2), 37-58 (doi: 10.1007/s00382-013-1719-7)

Rau F, Mauz F, Vogt S, Khalsa SJS and Raup B (2005) Illustrated GLIMS glacier classification manual. Glacier classification guidance for the GLIMS inventory. Institut für Physische Geographie, Freiburg/US National Snow and Ice Data Center, Boulder, CO

Rau F, Kargel JS and Raup BH (2006) The GLIMS Glacier Inventory of the Antarctic Peninsula. Earth Observer, 18(6), 9-11 
Raup B and Khalsa SJS (2010) GLIMS analysis tutorial. National Snow and Ice Data Center, Boulder, CO http://www.glims.org/ MapsAndDocs/assets/GLIMS_Analysis_Tutorial_a4.pdf

Raup B and 11 others (2007) Remote sensing and GIS technology in the Global Land Ice Measurements from Space (GLIMS) Project. Comput. Geosci., 33(1), 104-125 (doi: 10.1016/j.cageo. 2006.05.015)

Rea BR and Evans DJA (2007) Quantifying climate and glacier mass balance in north Norway during the Younger Dryas. Palaeogeogr., Palaeoclimatol., Palaeoecol., 246(2-4), 307-330 (doi: 10.1016/j.palaeo.2006.10.010)

Rea BR, Whalley WB, Evans DJA, Gordon JE and McDougall DA (1998) Plateau icefields: geomorphology and dynamics. In Owen LA ed. Mountain glaciation. (Quaternary Proceedings 6) Wiley, Chichester, 35-54

Rogerson RJ (1986) Mass balance of four cirque glaciers in the Torngat Mountains of northern Labrador, Canada. J. Glaciol., 32(111), 208-218

Rogerson RJ, Olson ME and Branson D (1986a) Medial moraines and surface melt on glaciers of the Torngat Mountains, northern Labrador, Canada. J. Glaciol., 32(112), 350-354

Rogerson RJ, Evans DJA and McCoy WD (1986b) Five-year growth of rock lichens in a Low-Arctic mountain environment, northern Labrador. Géogr. Phys. Quat., 40(1), 85-91

Royston P (1995) A remark on algorithm AS 181: the $W$-test for normality. J. R. Stat. Soc., Ser. C, 44(4), 547-551

Schiefer E and Menounos B (2010) Climatic and morphometric controls on the altitudinal range of glaciers, British Columbia, Canada. Holocene, 20(4), 517-523 (doi: 10.1177/ 0959683609356583)

Shahgedanova M, Nosenko G, Bushueva I and Ivanov M (2012) Changes in area and geodetic mass balance of small glaciers, Polar Urals, Russia, 1950-2008. J. Glaciol., 58(211), 953-964 (doi: 10.3189/2012JoG11J233)

Sharp M, Burgess DO, Cogley JG, Ecclestone M, Labine C and Wolken G (2011a) Extreme melt on Canada's Arctic ice caps in the 21st century. Geophys. Res. Lett., 38(11), L11501 (doi: 10.1029/2011GL047381)

Sharp $M$ and 8 others (2011b) Mountain glaciers and ice caps. In Snow, water, ice and permafrost in the Arctic (SWIPA): climate change and the cryosphere. Arctic Monitoring and Assessment Programme (AMAP), Oslo, 7-1-7-61
Solomina O, Ivanov M and Bradwell T (2010) Lichenometric studies on moraines in the Polar Urals. Geogr. Ann. A, 92(1), 81-99 (doi: 10.1111/j.1468-0459.2010.00379.x)

Staiger JKW and 7 others (2005) Quaternary relief generation by polythermal glacier ice. Earth Surf. Process. Landf., 30(9), 1145-1159 (doi: 10.1002/esp.1267)

Stix J (1980) Glaciers of the Nachvak Fiord region, northern Labrador. National Hydrology Research Institute, Environment Canada, Ottawa, Ont.

Stokes CR, Shahgedanova M, Evans IS and Popovnin VV (2013) Accelerated loss of alpine glaciers in the Kodar Mountains, south-eastern Siberia. Global Planet. Change, 101, 82-96 (doi: 10.1016/j.gloplacha.2012.12.010)

Svoboda F and Paul F (2009) A new glacier inventory on southern Baffin Island, Canada, from ASTER data: I. Applied methods, challenges and solutions. Ann. Glaciol., 50(53), 11-21 (doi: 10.3189/172756410790595912)

Tennant C, Menounos B, Wheate R and Clague JJ (2012) Area change of glaciers in the Canadian Rocky Mountains, 1919 to 2006. Cryosphere, 6(6), 1541-1552 (doi: 10.5194/tc-61541-2012)

Thompson LG and 6 others (2013) Annually resolved ice core records of tropical climate variability over the past 1800 years. Science, 340(6135), 945-950 (doi: 10.1126/science.1234210)

Wardle RJ, Van Kranendonk MJ, Mengel F and Scott D (1992) Geological mapping in the Torngat Orogen, northernmost Labrador: preliminary results. (Geological Survey Branch, Report 92-1) Newfoundland Department of Mines and Energy, St John's, Nfld, 413-429

Wardle RJ, Gower CF, Ryan B, Nunn G, James DT and Kerr A (1997) Geological map of Labrador, 1:1 million scale. (Geological Survey Map No. 97-07) Department of Mines and Energy, Government of Newfoundland and Labrador, St John's, Nfld

Way RG and Viau AE (in press) Natural and forced air temperature variability in the Labrador region of Canada during the past century. Theor. Appl. Climatol. (doi: 10.1007/s00704-0141248-2)

Wolken GJ, Sharp MJ and England JH (2008) Changes in lateNeoglacial climate inferred from former equilibrium-line altitudes in the Queen Elizabeth Islands, Arctic Canada. Holocene, 18(4), 629-641 (doi: 10.1177/0959683608089216)

MS received 25 October 2013 and accepted in revised form 21 June 2014 